JURNAL

MANAJEMEN PENDIDIKAN

PENELITIAN KUALITATIF

Vol. 5 No.2 Maret 2021: pp.54-60

e-ISSN: 2775-6904 | p-ISSN: 2502-9487

RESEARCH ARTICLE

OPEN ACCESS

\title{
ANALISIS MANAJEMEN PEMBINAAN ATLET SEPAK TAKWRAW PPLP RIAU Januarlis $^{1}$ \\ Caska $^{2}$ \\ Hasnah Faizah $\mathbf{A R}^{3}$
}

${ }^{1,2,3}$ Magister Administrasi Pendidikan Pascasarjana Universitas Riau

\begin{abstract}
Coaching is one of the things that must be done in PPLP because coaching is one of the key successes of PPLP. The existence of high coaching can be one of the capital for PPLP to achieve the expected goals. In order to uphold the coaching, coaching management is needed based on the theories reflected in management functions which consist of planning, organizing, implementing, and monitoring carried out to determine and achieve predetermined goals through the use of human resources and other resources. This research is a type of qualitative research, which is research that tends to deal with research problems that require exploration, where knowledge of the problem is still limited, about a detailed understanding of central phenomena. With data collection techniques carried out with interviews, observations, and documentation. Data processing procedures are carried out by informing checking tringulation techniques, as well as data checking. The results showed, 1) the planning of the coaching management work program has been carried out well, this is evident from the management of athlete coaching which is arranged for short and long term activities, in the implementation of the management of athletes that have been prepared when giving training materials can be implemented as when the management plan for athlete coaching is mutually agreed upon.2) the management of coaching management has been well established this as in the division of tasks and responsibilities in accordance with the decree issued by Dispora, 3) the execution of duties and responsibilities of human resources in charge of the implementer has been able to carry out the responsibilities properly, 4) supervision of the implementation of management management of this guidance has been carried out well, because supervision has been carried out by the leadership both directly and indirectly.
\end{abstract}

Key words: Management; Guidance, Planning; Organizing; Implementation; Supervision

\begin{abstract}
Abstrak: Pembinaan merupakan salah satu hal yang harus dilakukan di PPLP karena pembinaan adalah salah satu kunci sukses PPLP.Adanya pembinaan yang tinggi dapat menjadi salah satu modal bagi PPLP untuk mencapai tujuan yang diharapkan. Dalam rangka untuk menegakkan pembinaan tersebut maka dibutuhkan manajemen pembinaan dengan berpedoman pada teori - teori yang tergambar dalam fungsi - fungsi manajemen yang terdiri dari perencanaan, pengorganisasian, pelaksanaan, dan pengawasan yang dilakukan untuk menentukan serta mencapai sasaran yang telah ditentukan melalui pemanfatan sumber daya manusia dan sumber daya lainya. Penelitian ini merupakan jenis penelitian kualitatif, yaitu penelitian yang cenderung menangani masalah - masalah penelitian yang memerlukan eksplorasi, dimana pengetahuan tentang masalah masih terbatas, tentang pemahaman yang rinci tentang fenomena sentral.Dengan teknik pengumpulan data dilakukan dengan Wawancara, observasi, dan dokumentasi.Prosedur pengolahan data dilakukan dengan teknik tringulasi pengecekan informan, serta pemeriksaan data. Hasil penelitian menunjukan, 1) perencanaan terhadap program kerja manajemen pembinaan sudah dilakukan secara baikhal ini terbukti dari adanya manajemen pembinaan atlet yang disusun untuk kegiatan jangka pendek maupun jangka panjang, dalam pelaksanaannya manajemen pembinaan atlet yang sudah disusun tersebut saat pemberian materi latihan sudah dapat dilaksanakan sebagaimana ketika pembuatan perencanaan manajemen pembinaan atlet yang telah disepakati bersama.2) pengorganisasian manajemen pembinaan sudah terbentuk dengan baik hal ini sebagaimana dalam pembagian tugas dan tanggung jawab sesuai dengan surat keputusan
\end{abstract}


JURNAL

MANAJEMEN PENDIDIKAN Vol. 5 No.2 Maret 2021: pp.54-60

PENELITIAN KUALITATIF

e-ISSN: 2775-6904 | p-ISSN: 2502-9487

yang dikeluarkan Dispora, 3) pelaksanaan tugas dan tanggung jawabnya sumber daya manusia yang bertugas sebagai pelaksana tersebut sudah mampu menjalankan tanggung jawab sebagaimana mestinya, 4) pengawasan pelaksanaan pengelolaan manajemen pembinaan ini sudah terlaksana dengan baik, karena pengawasan sudah dilakukan oleh pimpinan baik secara langsung maupun tidak langsung.

Kata Kunci: Manajemen; Pembinaan; Perencanaan; Pengorganisasian; Pelaksanaan; Pengawasan

\section{PENDAHULUAN}

Perkembangan olahraga sepak takraw saat ini berkembang dengan pesat di Provinsi Riau, khususnya Kota Pekanbaru. Sepak takraw merupakan olahraga yang popular, hal ini dapat dilihat dari seringnya di adakannya pekan olahraga provinsi, pekan olahraga pelajar daerah. Dari sekian banyak cabang olahraga yang telah mengharumkan nama Provinsi Riau salah satunya pada cabang olahraga sepak takraw. Hal ini ditandai dengan beberapa tahun terakhir Pusat Pembinaan dan Latihan Pelajar (PPLP) sepak takraw Riau berhasil meraih prestasi yang baik dengan mampu meraih emas, perak dan perunggu. Regu sepaktakraw PPLP Riau, berhasil meraih emas pada kejuaraan nasional (Kejurnas) antar PPLP 20 - 25 Desember 2013 dalam GoRiau.com (23 Oktober 2013). Pada tahun selanjutnya 2014 PPLP Riau berhasil meraih 2 perak dan 1 perunggu dalam Metrosulteng.com. (29 September 2014). Satu tahun kemudian PPLP Riau berhasil meraih emas dalam Tribunnews.com ( 1 Agustus 2015 ). Sementara 2016 PPLP Riau mengalami kemerosotan prestasi hanya sampai di delapan besar saja dalam Tribunnews.com (11 November 2016). Dipertengahan tahun ini PPLP Riau, berhasil meraih emas pada Kejuaraan Nasional 17-22 Juli 2017 di Sulawesi Selatan dalam Pekanbaru Tribunnews.com (21 juli 2017).

Fenomena tersebut tidak terlepas dari kerja keras dari semua pihak mulai dari (1) perencanaan, (2) pengorganisasian, (3) pelaksanaan dan (4) pengawasan. Pertama, perencanaan dimulai dari perekrutan yang dilakukan $2 \mathrm{X}$ dalam setahun oleh dinas pemuda dan olahraga. Dinas pemuda dan olahraga melakukan perencanaan dalam penjaringan atlet dengan cara melayangkan surat kepada KONI kabupaten dan kota. Tiap pengurus cabang olahraga mengirimkan bebarapa atlet yang telah mengikuti penjaringan dikabupaten kota. Pada akhirnya yang berhak mengikuti seleksi dan pemusatan pembinaan adalah atlet yang terbaik dari setiap kabupaten kota. Kedua, pengorganisasian dilakukan setelah seleksi dan yang terpilih akan di panggil untuk bergabung di asrama PPLP Riau. Calon atlet berada diluar daerah diwajibkan mengurus surat pindah ke Pekanbaru. Ketiga, pelaksanaan, dimulai dari bergabung di asrama dan pemusatan latihan dilapangan. Keempat, pengawasan dilakukan oleh Dispora, KONI dan semua pihak yang terkait didalamnya. Kelima, hasil pembinaan akan menjadi evaluasi untuk perbaikan ketahun selanjutnya.

Pencapaian prestasi puncak dalam olahraga dapat dicapai melalui proses pembinaan yang sistematik, terencana, teratur dan berkesinambungan. Oleh karena itu, pencapaian prestasi puncak perlu dijabarkan dalam suatu konsep yang menyeluruh dalam suatu pola pembinaan yang berjenjang. Proses pembinaan olahraga pelajar yang rutin harus diukur dengan kompetisi antara lain kejuaraan remaja, yunior, antar PPLP dan multi even pada Pekan Olahraga Provinsi, Pekan Olahraga Pelajar Daerah, Pekan Olahraga Nasional.

Pelajar merupakan bagian yang potensial dibidang pembangunan olahraga.Pembinaan olahraga ditingkat pelajar mempunyai peran strategis untuk menjaring calon atlet yang memiliki potensi menjadi atlet yang berprestasi di tingkat nasional dan internasional. Salah satu strategi yang paling mendasar dalam upaya mewujudkan sumber daya manusia khususnya dibidang olahraga adalah dengan memusatkan perhatian dan orientasi pembangunan sedini mungkin yaitu dengan melakukan melakukan pembinaan dan pengembangan olahraga bagi olahraga sejak dini lilik dalam Hana Puspita Santoso Dkk (2017:157). Penyelengara proses pembinaan salah satunya dilakukan oleh PPLP dibawah Dinas Pemuda dan Olahraga. Dalam proses pembinaan menuju prestasi yang setinggi tingginya Pusat pembinaan dan latihan pelajar berada pada tempat yang strategis, karena berada di posisi terdepan dan menjadi ujung tombak pembinaan prestasi.

Proses pembinaan prestasi olahraga banyak faktor yang harus di perhatikan,antara lain tujuan pembinaan yang jelas, program latihan yang sitematis, materi dan metode latihan yang tepat. Disamping 
JURNAL

MANAJEMEN PENDIDIKAN Vol. 5 No.2 Maret 2021: pp.54-60

PENELITIAN KUALITATIF

e-ISSN: 2775-6904 | p-ISSN: 2502-9487

itu perlu adanya pertimbangan karakteristik atlet yang dibina baik secara fisik dan psikologi, kemampuan pelatih , sarana dan prasarana / fasilitas serta kondisi lingkungan pembinaan.

Menurut Monty P. Satiadarma dalam Eva Yunida dkk (2016:126) mengatakan membina prestasi olahraga, serta atlet tidak dapat dilakukan dalam waktu satu malam, melainkan melalui berbagai proses dan tahapan dalam satu kurun waktu tertentu. Pusat pembinaan dan latihan pelajar harus memiliki latar belakang dan perencanaan pembinaan sepak takraw yang jelas untuk atlet atletnya.Tidak hanya asal berdiri, tetapi memiliki program terencana untuk memajukan para atletnya.Posisi pelatih dalam menjalankan program pembinaannya masih mengalami banyak kendala dan perlu mendapatkan perhatian.

Perencanaan merupakan proses terpenting dari semua fungsi manajemen karena tanpa perencanaan fungsi - fungsi lainya tak dapat berjalan. Seperti fungsi pengorganiasian, pengarahan, penyusunan personalia dan pengawasan.Pelatih menggunakan fungsi pengorganisasian untuk mempermudah dalam pengawasan dan menentukan orang yang dibutuhkan untuk melaksanakan tugas tugas yang telah dibagi bagi tersebut.

Rencana strategis Dinas Pemuda dan Olahraga, diposisikan pada upaya-upaya melakukan pemberdayaan olahraga di Provinsi Riau. Olahraga pada hakikatnya merupakan bagian dari proses dan pencapaian tujuan pembangunan nasional sehingga keberadaan dan peranan olaharaga dalam kehidupan bermasyarakat, berbangsa dan bernegara harus ditempatkan pada kedudukan yang jelas. Oleh karena itu, perhatian terhadap olahraga dan pentingnya nilai-nilai olahraga untuk meningkatkan kesejahteraan individu, kelompok masyarakat pada umumnya perlu terus ditumbuh kembangkan melalui proses yang terencana dan sistematik, berjenjang dan berkelanjutan mulai dari tahap permasalahan, perekrutan, pembibitan sampai pada pencapaian hasil prestasi yang maksimal, sehingga membentuk sebuah bangunan sistem pembinaan keolahragaan nasional seperti yang diharapkan sesuai dengan Undangundang Nomor 3 Tahun 2005 tentang sistem keolahragaan nasional.

Pemerintah Provinsi Riau, pemerintah melalui Dinas Pemuda dan Olahraga melakukan peningkatan olahraga secara bertahap melalui berbagai kegiatan, salah satunya membentuk PPLP sebagai wadah pendidikan dan pembinaan atlet pelajar berbakat yang merupakan wujud dari sistim penyelenggaraan pelatihan untuk mencapai hasil yang diinginkan, meningkatkan prestasi dalam ajang ke olahragaan nasional dan internasional. Pembentukan PPLP bertujuan untuk menciptakan atlet pelajar yang potensial dan berprestasi baik dibidang pendidikan maupun bidang olahraga yang dapat dibina secara terpusat sehingga proses pelatihan bagi para atlet akan lebih intensif dan pendidikan akademisnya tidak tertinggal. PPLPcabang olahraga yaitu sepak takraw di Provinsi Riau didirikan sejak tahun 1995 dibawah binaan Dinas Pemuda dan Olahraga Provinsi Riau.PPLP sepak takraw Riau telah membina 21 Jumlah atlet pada tahun 2017. 15 diantaranya atlet putra dan 6 atlet putri dimana atlet tersebut dilatih oleh 3 orang pelatih.Selain pelatih dan atlet dari setiap cabang olahraga, peran pemerintah juga amat diperlukan dalam pembinaan prestasi atlet pelajar. Dukungan dari pemerintah akan mendorong prestasi para atlet pelajar, dukungan itu berupa penyedian fasilitas latihan yang memadai sesuai standar, mulai dari vanue (lapangan), peralatan serta fasilitas pendukung lainnya.

Berdasarkan Undang-undang Republik Indonesia No. 3 Tahun 2005 tentang sistem keolahragaan nasional pasal 20 ayat 3 , disebutkan bahwa: "Olahraga prestasi dilaksanakan melalui proses pembinaan dan pengembangan secara terencana, berjenjang dan berkelanjutan dengan dukungan ilmu pengetahuan dan teknologi keolahragaan". Lebih lanjut dalam pasal 20 ayat 5 juga disebutkan bahwa: "Untuk memajukan olahraga prestasi, Pemerintah,pemerintah daerah, atau masyarakat dapat mengembangkan :

a. Perkumpulan olahraga;

b. Pusat penelitian dan pengembangan ilmu pengetahuan dan teknologi olahraga;

c. Sentra pembinaan olahraga preststasi;

d. Pendidikan dan pelatihan tenaga keolahragaan;

e. Prasarana dan saran olahraga prestasi;

f. Sistem pemanduan dan pengembangan bakat olahraga;

g. Sistem informasi keolahragaan; dan

h. Melakukan uji coba kemampuan prestasi olahragawan tingkat daerah, nasional, dan internasional sesuai dengan kebutuhan. 
JURNAL

MANAJEMEN PENDIDIKAN

Vol. 5 No.2 Maret 2021: pp.54-60

e-ISSN: 2775-6904 | p-ISSN: 2502-9487

Jika undang-undang tersebut dijalankan sebagaimana mestinya, tentunya akan tercipta manajemen pembinaan atlet yang baik, dan akan lahir atlet-atlet yang handal. Sebab pelaksana pembinaan memiliki minat, pengetahuan, kepemimpinan, kemampuan manajerial, dan pendanaan yang baik, serta tenaga keolahragaan yang dipilih oleh pelaksana pembinaan memiliki kualifikasi dan sertifikat kompetensi dalam bidang olahraga.

Dalam penelitian ini penulis tidak membahas penampilan atlet dari keseluruhan faktor, namun lebih fokus pada faktor eksternalnya, yaitu Analisis Manajemen Pembinaan Atlet Sepak Takraw PPLP Riau.

\section{METODOLOGI PENELITIAN}

\section{RancanganPenelitian}

Rancangan penelitian dapat dilihat dari gambar berikut ini;

\begin{tabular}{|l|}
\hline Observasi \\
\hline Observasi Lanjutan \\
\hline Wawancara \\
\hline Studi Dokumentasi \\
\hline
\end{tabular}

\section{Subjek Penelitian}

Untuk mengetahui informasi - informasi secara lebih mendalam, peneliti memilih informan yang dianggap menguasai tugas di bidang masing - masing, yaitu: Pembina dan penanggung jawab pusat pembinaan dan latihan olahraga pelajar ( PPLP) Riau , para pelatih PPLP sepak takraw Riau

\section{Intrumen Penelitian}

Untuk menggunakan teknik yang telah di tentukan dibutuhkan alat yang dipakai untuk mengumpulkan data yaitu: yang dikembangkan oleh penulis ( observasi, wawancara, dan dokumentasi).

\section{Teknik Pengumpulan Data}

Untuk mendapatkan data yang dibutuhkan secara mendalam tentang manajemen pembinaan atlet sepak takraw PPLP Riau maka perlu menyusun pedoman wawancara yang berisikan pertanyaan pertanyaan penelitian, menurut Creswell dan Moleong dalam prosedur pengumpulan data penelitian kualitatif mempunyai 4 dasar, yaitu: (1) Observations, (2) Interviews, (3) Dokuments, dan (4) Visual Images.

\section{HASIL DAN PEMBAHASAN}

Berdasarkan hasil penelitian dan analisis data yang terkumpul dari observasi, wawancara, studi dokumentasi dan observasi dapat diketahui bahwa manajemen pembinaan atlet sepak takraw PPLP Riau telah melaksanakan proses manajemen dengan baik sesuai dengan fungsi - fungsinya.

\section{Perencanaan}

Perencanaan manajemen pembinaan yang merupakan bagian dari urusan pelatih kepala berdasarkan hasil keputusan bersama yang melibatkan banyak pihak, yang terdiri dari: pelatih kepala, asisten pelatih serta Dispora yang juga turut dilibatkan dalam penyusunan perencanaan program kerja manajemen pembinaan di PPLP sepak takraw Riau.

Perlibatan banyak pihak dalam penyusunan rencana program kerja ini dimaksudkan agar memperoleh banyak masukan untuk pencapaian tujuan yang telah direncanakan dimasa yang akan 
JURNAL

MANAJEMEN PENDDIKAN Vol. 5 No.2 Maret 2021: pp.54-60

PENELITIAN KUALITATIF

e-ISSN: 2775-6904 | p-ISSN: 2502-9487

datang. Perencanaan program kerja manajemen pembinaan ini terdiri dari program jangka pendek dan jangka panjang yang dibuat untuk empat tahun kedepan.

Hal -hal yang dimuat dalam program kerja manajemen pembinaan terdiri dari: dasar, maksud tujuan strategis, sasaran, program kerja jangka panjang maupun jangka pendek, hal ini didasari oleh kepentingan bersama untuk menciptakan suasana kegiatan latihan yang efektif dan efisien dan kondusif.

Adapun perencanaan program kerja jangka pendek bidang atlet yang menyangkut pembinaan teknik dan fisik merupakan suatu rencana pencapaian tujuan dalam kurun waktu tiga bulan sampai satu tahun diantaranya:

- Menyusun program kerja atau program latihan

- Menyusun jadwal latihan

- Membuat peraturan atlet

- $\quad$ Membuat skor sangsi pelanggaran atlet

- $\quad$ Membina atlet yang bermasalah

- Memantau kegiatan latihan

- Menjalin hubungan baik dengan pelatih dan atlet

Sedangkan program jangka panjang merupakan suatu rencana pencapaian tujuan latihan dalam kurun waktu 1- 4 tahu, diantaranya

- $\quad$ Membangun PPLP yang berwawasan disiplin dan patuh terhadap aturan yang berlaku

- $\quad$ Mencetak atlet yang berprestasi

- $\quad$ Mengembangkan bakat atlet sesuai dengan spesialisasi

- $\quad$ Mengirimkan wakil atau duta atlet yang mengikuti event Nasional maupun Internasional

Program kerja jangka panjang dan jangka pendek ini sudah dilaksanakan secara baik oleh tim manajemen pembinaan PPLP ini, hal ini terbukti dari adanya perlibatan berbagai pihak dalam penyusunan program kerja, sehingga pelaksanaan dari setiap program dapat dilaksanakan dan diawasi oleh seluruh elemen yang terlibat dalam penyusunan `perencanaan.

Jadi dari hasil penelitian yang penulis lakukan dapat diketahui bahwa proses penyusunan perencanaan sudah bagus, yaitu sudah meliputi unsur - unsur proses perencanaan dalam manajemen yang sesuai dengan langkah langkah, sebagai berikut:

- Menentukan tujuan perencanaan ;

- $\quad$ Menentukan tindakan untuk mencapai tujuan;

- Mengembangkan dasar pemikiran kondisi mendatang;

- $\quad$ Mengidentifikasi cara untuk mencapai tujuan mendatang;

- $\quad$ Mengimplementasi rencana tindakan dan mengevaluasihasilnya

\section{Pengorganisasian}

Pelatih kepala yang diangkat berdasarkan surat keputusan darikadis Dispora tentunya sebagai pelindung dan mengawasi tugas asisten satu dan asisten dua, adapun tugas dari asisten satu dan asisten dua adalah mengatur jadwal latihan dan memeberikan materi latihan".

Tugas pokok dan fungsi dari masing masing jabatan yang diemban oleh personil yang ada dalam tim manajemen pembinaan PPLP secara struktural terlihat bahwa Dispora dalam naungan Kemenpora sebagai penanggung jawab tertinggi dan mengambil yang berkaitan dengan kebijakan yang diambil dalam pelaksanakan kegiatan pembinaan sehari hari. Pelatih kepala sebagai pelaksana kegiatan pembinaan bersama asisten pelatih. Dari hasil observasi dan wawancara yang penulis lakukan dapat dilihat secara struktural manajemen pembinaan atlet PPLP sepak takraw Riau sudah melaksanakan fungsi pengorganisasian dengan baik, hal ini terlihat dari pelaksanaan empat komponen dari organisasi yang dilaksanakan yaitu sebagai berikut:

1. Work.

2. Empoyees

3. Relationship

4. Environment 
JURNAL

MANAJEMEN PENDIDIKAN Vol. 5 No.2 Maret 2021: pp.54-60

PENELITIAN KUALITATIF

e-ISSN: 2775-6904 | p-ISSN: 2502-9487

baik.

Dari pemaparan dan data dokumentasi pengorganisasian telah tersusun dan terlaksana dengan

\section{Pelaksanaan}

Pelaksanaan manajemen pembinaan atlet sepak takraw PPLP Riau bahwa dalam proses pelaksanaan program kerja manajemen pembinaan atlet PPLP ini telah berjalan sebagaimana mestinya. Setiap pelanggaran yang dilakukan oleh atlet sudah diproses dan ditindak lanjuti oleh yang berwenang.Hasil wawancara juga menunjukan bahwa tidak ada terdapat atlet yang melanggar aturan kedisiplinan dalam pemusatan pembinaan ini.

Selain itu dalam proses pelaksanaan pembinaan semuanya sudah sesuai prosedur. Namun dari hasil temuan penulis didapatkan dilapangan yang tidak sesuai adalah pelaksanaan daftar isian pelaksanaan anggaran ( DIPA) yang semestinya dana yang sudah dianggarkan sudah dapat dikelola tetapi terlambat untuk disetujui untuk digunakan yang dapat mengakibatkan terganggu nya sistem pembinaan PPLP ini. Dari hasil temuan unsur - unsur pelaksanaan manajemen telah dilaksanakan dengan baik yaitu adanya aktivitas yang mengarahkan atlet untuk disiplin dalam berbagai hal dan perbuatan dan hal ini memang dilaksanakan di PPLP sepak takraw Riau.

\section{Pengawasan}

Pengawasan diambil oleh Dispora dalam melakukan pengawasan adalah mengawasi kinerja pelatih, asisten platih.Motivasi dan evaluasi terhadap laporan dan melakukan evaluasi terhadap pelaksanaan program kerja yang sudah dibuat.Hal ini dilakukan agar pencapaian maksud dan tujuan dapat terlaksana sesuai dengan perencanaan yang sudah disusun, serta mencarikan solusi jika terdapat suatu permasalahan dari pelaksanaan manajemen pembinaan atlet.Tindakan dan tahapan dalam melakukan pengawasan yang dilakukan oleh pelatih kepala sudah dilaksanakan dengan baik terhadap asisten pelatih, untuk pelaksanaan pengambilan keputusan dilaksanakan sesuai dengan seharusnya sehingga memang untuk melakukan evaluasi terhadap tersebut perlu dilakukan.

\section{SIMPULAN}

Hasil penelitian yang penulis lakukan dan temuan dilapangan maka dapat disimpulkan bahwa manajemen pembinaan atlet sepak takraw PPLP Riau berdasarkan fungsi - fungsi manajemen yaitu perencanaan, pengorganisaian, pelaksanaan dan pengawasan, adalah sebagai berikut:

a) Perencanaan penyusunan perencanaan sebagai dasar dalam melaksanakan kegiatan dalam pencapaian maksud dan tujuan PPLP sudah disusun dan dirancang dengan baik. Perencanaan manajemen pembinaan atlet yang sudah disusun tersebut terlaksana dengan baik, hal ini terbukti dari adanya manajemen pembinaan atlet yang disusun untuk kegiatan jangka pendek maupun jangka panjang, dalam pelaksanaannya manajemen pembinaan atlet yang sudah disusun tersebut saat pemberian materi latihan sudah dapat dilaksanakan sebagimana ketika pembuatan perencanaan manajemen pembinaan atlet yang telah disepakati bersama.

b) Pengorganisian,Fungsi manajemen pembinaan atlet sudah terbentuk dan tersusun dengan baik hal ini sebagai dasar dalam pembagian tugas dan tanggung jawab sesuai dengan surat keputusan yang mencantumkan tugas dan tanggung jawab dari masing masing jabatan yang diemban oleh setiap orang dalam teamwork dalam pelaksanaan tugas dan tanggung jawabnya sumber daya manusia yang bertugas sebagai pelaksana tersebut sudah mumpuni dalam bidang manajemen pembinaan. Ditambah lagi dalam pengambilan keputusan akhir pelatih kepala selaku pimpinan selalu berkoordinasi dengan 2 asisten pelatih agar melaksanakan secara konsinten sesuai dengan yang sudah digariskan dan disepakati bersama.

c) Pelaksanaan Fungsi pelaksanaan manajemen pembinaan atlet dapat dilaksanakan dengan baik.diantaranya selalu mengawasi aktivitas yang berhubungan dengan pembinaan atlet, memberikan laporan tertulis maupun catatan tidak tertulis seperti laporan akhir kegiatan, hasil 


\section{JURNAL}

\section{MANAJEMEN PENDDDKAN Vol. 5 No.2 Maret 2021: pp.54-60}

PENELITIAN KUALITATIF

pertandingan Selain itu dalam proses pelaksanaan pembinaan semuanya sudah sesuai prosedur. Namun dari hasil temuan penulis didapatkan dilapangan yang tidak sesuai adalah pelaksanaan daftar isian pelaksanaan anggaran ( DIPA) yang semestinya dana yang sudah dianggarkan sudah dapat dikelola tetapi terlambat untuk disetujui untuk digunakan yang dapat mengakibatkan terganggu nya sistem pembinaan PPLP ini (4) Pengawasan Pelaksanaan fungsi pengawasan adalah fungsi manajemen yang dilakukan untuk dikeluarkan oleh pihak Dinas Kepemudaan dan Olahraga Provinsi Riau yang.

Mengawasi kinerja tim yang terlibat dalam pengelolaan manajemen pembinaan atlet, dan untuk melihat sejauh mana meningkat atau bahkan penurunan kinerja tim dalam pencapaian tujuan serta mencarikan solusi terhadap permasalahan yang terjadi. Dalam manajemen pengawasan pelaksanaan pengelolaan manajemen pembinaan ini sudah terlaksana dengan baik, karena pengawasan sudah dilakukan oleh pimpinan baik secara langsung maupun tidak langsung.Dalam melakukan pengawasan terhadap kinerja bawahan pelatih kepala selaku penanggung jawab dan 2 asisten pelatih bertanggung jawab dalam memanage pembinaan atlet selalu memberikan motivasi pada bawahan.Dalam melakukan evaluasi dapat dilaksanakan sebagaimana mestinya karena sebenarnya pihak manajemen PPLP sudah mengetahui penyebab tidak terlaksananya fungsi - fungsi manajemen dengan baik.

\section{DAFTAR PUSTAKA}

Eva Yunida, Sugiarto, Tommy Soenyoto (2017) Manajemen Pembinaan Merdeka Basket Club (MMBC) Pontianak Kalimantan Barat Tahun 2016. Jurnal Pendidikan Olahraga. Semarang

GoRiau. Edisi, 23 0ktober 2013

Hana Puspita, Tandiyo Rahayu, Sety a Rahayu. (2017). Pembinaan Bulutangkis di Kota Magelang.( Penelitian Evaluatif Klub- Klub Bulutangkis di Kota Magelang). Jurnal Pendidikan Olahraga. Semarang

Tribunnews. Edisi, 1 Agustus 2015

Tribunnews. Edisi,11 November 2016

Tribunnews. Edisi, 21 Juli 2017

Undang-undang republik indonesia. Nomor 3 tahun 2005 